\section{KEKUATAN MENGIKAT IZIN USAHA PERTAMBANGAN DALAM HUKUM PERTAMBANGAN DI INDONESIA ${ }^{1}$ Oleh : Clara C. M. U. Rusyuniardi ${ }^{2}$}

\section{ABSTRAK}

Tujuan dilakukannya penelitian ini adalah untuk mengetahui bagaimana Izin Usaha Pertambangan terhadap Perusahaan Pertambangan ditinjau dari Undang-Undang Nomor 4 Tahun 2009 tentang MINERBA dan bagaimana implikasi Izin Usaha Pertambangan berdasarkan Undang-Undang Nomor 4 Tahun 2009 tentang MINERBA bagi Perusahaan Pertambangan di Indonesia. Dengan menggunakan metode penelitian yuridis normatif, disimpulkan: 1 . Dengan adanya Undang-Undang Nomor 4 Tahun 2009 tentang Mineral dan Batubara telah merubah sistem investasi pertambangan batubara dari sistem kontrak menjadi sistem perizinan. Jika dalam sistem kontrak kedudukan antara pemerintah dengan investor adalah sama/sejajar dimana pemerintah berlaku sebagai pelaku usaha, berbeda halnya dalam sistem perizinan yang membuat kedudukan pemerintah menjadi lebih tinggi dari investor, dimana pemerintah berkedudukan sebagai regulator. Perubahan kedudukan ini dilihat dari aspek ketatanegaraan adalah sebuah langkah yang baik karena pemerintah sebagai badan hukum publik tidak menurunkan derajatnya menjadi badan hukum privat sebagaimana yang telah dilakukan pemerintah dalam sistem kontrak. 2. Keberadaan pasal 169 (b) UU No. 4 Tahun 2009 telah membawa implikasi serius tentang pertambangan mineral dan batubara di sektor pertambangan. Bila pasal 169 (a) UndangUndang Nomor 4 Tahun 2009 mengakui keberadaan KK/PKP2B, pasal 169 (b) justru mengabaikannya. Perusahaan Pertambangan pun juga turut menyesuaikan dengan aturan dari pemerintah yang ada, sehingga ketegasan dari aturan yang dikeluarkan tersebut bersifat tegas dan mengikat perusahaan pertambangan yang ada.

Kata kunci: Kekuatan Mengikat, Izin Usaha, Pertambangan, Hukum Pertambangan.

\footnotetext{
${ }^{1}$ Artikel Skripsi. Dosen Pembimbing: Frans Maramis, S,H. M.H; Dr. Muhammad Hero Soepeno, S.H., M.H

2 Mahasiswa pada Fakultas Hukum Unsrat, NIM. 16071101262
}

\section{PENDAHULUAN}

\section{A. Latar Belakang}

Proses izin usaha pertambangan mineral dan batubara tersebut, maka dalam system pemerintah telah diatur pembagian kewenangan antara Pemerintah Pusat, Pemerintah Provinsi, dan Pemerintah Kabupaten/Kota. Kewenangan tersebut berdasar pada Undang-Undang Nomor 32 Tahun 2004 tentang Pemerintahan Daerah yang diatur lebih spesifik dalam Peraturan Pemerintah Nomor 38 Tahun 2007 tentang Pembagian Urusan Pemerintah, Pemerintah Daerah Provinsi, Dan Pemerintah Daerah Kabupaten/Kota ${ }^{3}$. Namun, saat ini telah dikeluarkan Undang-Undang Nomor 23 Tahun 2014 tentang Pemerintahan Daerah untuk mengganti Undang-Undang 32 Tahun 2004. Mengenai kaitannya dengan energi dan sumber daya mineral, bidang tersebut menjadi urusan pemerintahan konkuren pilihan yang dibagi antara Pemerintah Pusat dan Daerah Provinsi dan Daerah kabupaten/kota. Berbeda dengan undang-undang sebelumnya, pengurusan izin usaha pertambangan yang dimiliki oleh pemerintah kabupaten/kotaberalih menjadi kewenangan pemerintah provinsi dan pemerintah pusat.

Permasalahan pun muncul ketika ditetapkannya Undang-Undang Nomor 4 Tahun 2009 tentang Pertambangan Mineral dan Batubara ini. Dimana terdapat beberapa perusahaan pertambangan yang masih memiliki kontrak yang aktif dengan pemerintah Indonesia yang bertentangan dengan ketentuan yang terdapat dalam Undang-Undang tersebut. Sehingga pemerintah pun harus segera mengambil kebijakan agar tidak menyalahi aturan yang telah dibuat tersebut.

Masalah selanjutnya adalah pasca ditetapkannya undang-undang minerba ini terdapat beberapa aturan-aturan yang cukup berbeda dengan aturan-aturan yang terdapat di dalam Undang-Undang No 11 Tahun 1967 tentang Ketentuan-Ketentuan Pertambangan. Seperti adanya perbedaan wilayah pertambangan yang diijinkan untuk diusahakan.

\footnotetext{
${ }^{3}$ Lampiran Peraturan Pemerintah Nomor 38 Tahun 2007 tentang Pembagian Urusan Pemerintah, Pemerintah Daerah Provinsi, Dan Pemerintah Daerah Kabupaten/Kota bagian Pembagian Urusan Pemerintah Bidang Energi dan Sumber Daya Mineral
} 
Dalam Undang-Undang Nomor 11 Tahun 1967 tidak diatur secara pasti mengenai luas wilayah pertambangan yang dapat diusahakan. Selanjutnya dalam UU No.11 Tahun 1967 juga tidak diatur adanya divestasi bagi perusahaan pertambangan. Perusahaan pertambangan juga tidak dituntut untuk melakukan pengolahan dan pemurnian bahan tambang di dalam negeri ${ }^{4}$.

Dikarenakan masalah - masalah yang diuraikan di atas menyebabkan peneliti pun mengambil permasalahan tersebut untuk menjadi bahan penelitian ini.

\section{B. Rumusan Masalah}

Rumusan masalah yang akan dibahas lebih rinci dalam tulisan ini terbagi menjadi dua bagian yaitu:

1. Bagaimana Izin Usaha Pertambangan terhadap Perusahaan Pertambangan ditinjau dari Undang-Undang Nomor 4 Tahun 2009 tentang MINERBA?

2. Bagaimana implikasi Izin Usaha Pertambangan berdasarkan UndangUndang Nomor 4 Tahun 2009 tentang MINERBA bagi Perusahaan Pertambangan di Indonesia?

\section{Metode Penelitian}

Metode penelitian yang digunakan dalam tulisan ini adalah metode penelitian hukum kepustakaan yang lazimnya disebut "Legal Research atau Legal Research Instruction" yaitu melakukan penelitian kepustakaan dari berbagai bahan pustaka yang berhubungan dengan materi permasalahan. Selanjutnya data dan informasi yang diperoleh sebagai bahan primer dan sekunder sebagai bahan rujukan bidang hukum di deskripsikan dan di integrasikan agar memperoleh informasi yang akurat untuk menjawab permasalahan.

Penelitian dilakukan bersifat normatif dengan jenis penelitian hukum yang mengambil

\footnotetext{
4 Badan Pengkajian dan Pengembangan Kebijakan Perdagangan, Pusat Kebijakan Perdagangan Luar Negeri.Analisis Dampak Kebijakan Pelarangan Ekspor Raw Material Tambang Dan Mineral.Jakarta.2013.hal 4-5. http://www.kemendag.g.id/files/pdf/2015/02/02/analisisdampak-kebijakan1422852872.pdf (diakses pada 2 November 2019)

5 Soerjono Soekanto. Sri Mamudji. Penelitian Hukum Normatif Suatu Tinjauan Singkat. Jakatra. PT. RajaGrafindo Persada. 2013. hlm. 23.
}

data kepustakaan. Penelitian yuridis normatif, yang merupakan penelitian utama dalam penelitian ini, adalah penelitian hukum kepustakaan. Dalam penelitian ini bahan pustaka merupakan data dasar penelitian yang digolongkan sebagai data sekunder.

\section{PEMBAHASAN}

\section{A. Status Izin Usaha Pertambangan terhadap Perusahaan Pertambangan}

Kehadiran Undang-Undang Nomor 4 Tahun 2009 tentang Pertambangan Mineral dan Batubara telah merubah pola kegiatan pertambangan di Indonesia dengan ditinggalkannya sistem Kuasa Pertambangan dan KK menjadi sistem perizinan6. Perubahan lain mengenai pengaturan pengusahaan pertambangan antara lain meliputi adanya pengaturan wilayah pertambangan, perubahan bentuk usaha pertambangan, hilangnya perbedaan perlakuan antara badan usaha domestik dan badan usaha dengan modal asing.

Setelah diundangkannya Undang-Undang Pemerintahan Daerah yang baru, kewenangan pemerintah kabupaten/kota terhadap pengelolaan izin usaha pertambangan dihapuskan dan dialihkan kepada pemerintah pusat dan pemerintah provinsi. Namun perubahan ini tidak serta merta merubah sistem dan mekanisme perizinan yang telah berlaku sebelumnya. Sistem dan mekanisme mengenai permohonan izin usaha pertambangan tetap dilaksanakan sesuai ketentuan perundang-undangan yang berlaku, yaitu Undang-Undang Nomor 4 Tahun 2009 tentang Pertambangan Mineral dan Batubara serta peraturan pelaksananya yaitu Peraturan Pemerintah Nomor 23 Tahun 2010 tentang Pelaksanaan Kegiatan Usaha Pertambangan Mineral dan Batubara. Perubahan hanya terletak pada kewenangan pemberian izin yang pada awalnya adalah wewenang Walikota/Bupati menjadi kewenangan Gubernur. Sistem dan mekanisme yang telah berjalan sedemikian rupa tidak mudah untuk dirubah, maka dalam pelaksanaannya permohonan izin usaha pertambangan tetap menggunakan ketentuan yang telah berlaku.

Keberadaan Undang-Undang Nomor 4 Tahun 2009 tentang Mineral dan Batubara telah merubah sistem investasi pertambangan

\footnotetext{
${ }^{6}$ Adrian Sutedi, 2011, Op.cit, hal 105
} 
batubara dari sistem kontrak menjadi sistem perizinan. Jika dalam sistem kontrak kedudukan antara pemerintah dengan investor adalah sama/sejajar dimana pemerintah berlaku sebagai pelaku usaha/player, sedangkan dalam sistem perizinan kedudukan pemerintah menjadi lebih tinggi dari investor, dimana pemerintah berkedudukan sebagai regulator. Perubahan kedudukan ini dilihat dari aspek ketatanegaraan adalah sebuah langkah yang baik karena pemerintah sebagai badan hukum publik tidak menurunkan derajatnya menjadi badan hukum privat sebagaimana yang dilakukan pemerintah dalam sistem kontrak.

Kedudukan yang lebih tinggi ini tentunya akan membuat kedudukan pemerintah sebagai regulator menjadi lebih efektif dibandingkan dengan kedudukan dalam sistem kontrak yang menjadikan pemerintah sebagai regulator dan pemain secara langsung. Peranan pemerintah pusat dan pemerintah daerah menjadi begitu vital dalam sektor pertambangan khususnya dalam pengaturan mengenai regulasi pertambangan batubara, petunjuk dan kebijakan serta standar-standar yang berkaitan dengan sektor penambangan batubara.

Dalam Undang-Undang Nomor 1 Tahun 1967 tentang Ketentuan Pokok-Pokok Pertambangan dibedakan antara cara memperoleh hak pengusahaan pertambangan, untuk usaha pertambangan yang dilakukan oleh investor dalam negeri adalah Kuasa Pertambangan (KP) dan untuk investor asing adalah dengan KK bagi pertambangan mineral, dan PKP2B untuk pertambangan batubara. Sedangkan dalam Undang-Undang Nomor 4 Tahun 2009 tentang Pertambangan Mineral dan Batubara sudah tidak ada pembedaan yaitu hanya melalui Izin Usaha Pertambangan (IUP) ${ }^{7}$.

Ketentuan dari UU Minerba No. 4 Tahun 2009 selanjutnya diatur dalam Peraturan Pemerintah No. 22 Tahun 2010 tentang Wilayah Pertambangan, Peraturan Pemerintah No. 23 Tahun 2010 tentang Pelaksanaan Kegiatan Usaha Pertambangan Mineral dan Batubara sebagaimana diubah dengan Peraturan Pemerintah No. 24 Tahun 2012 dan terakhir diubah dengan Peraturan Pemerintah No. 77 Tahun 2014, Peraturan Pemerintah No. 55 Tahun 2010 tentang Pembinaan dan

\footnotetext{
7 Abrar Saleng, 2004, Hukum Pertambangan, hal 26 Yogyakarta,
}

Pengawasan Penyelenggaraan Pengelolaan Usaha Pertambangan Mineral dan Batubara, dan Peraturan Pemerintah No. 78 Tahun 2010 tentang Reklamasi dan PascaTambang. Dari ketiga bentuk perizinan di atas, tidak secara jelas dapat diketahui bentuk perizinan yang mana sebagai pengganti dari kontrak karya untuk perusahaan tambang modal asing. Apakah IUPK dimaksudkan sebagai pengganti kontrak karya?. Kenapa IUPK dikatakan khusus sementara sistem pengelolaan lain, seperti IPR dan IUP tidak dikatakan khusus?. Menurut $\mathrm{H}$. Salim HS, kita harus menganalisis dan mengkaji ketentuan-ketentuan yang tercantum dalam Undang-Undang No. 4 Tahun 2009 dan berbagai peraturan pelaksanaannya. IUPK dikatakan khusus, harus dapat dikaji dari berbagai aspek berikut ini:

1) Pejabat yang berwenang untuk menerbitkan IUPK hanya Menteri Energi dan Sumber Daya Mineral, sementara itu, pejabat yang berwenang menerbitkan IUP, meliputi Menteri Energi dan Sumber Daya Mineral, Gubernur atau Bupati/Walikota.

2) Pemohon yang dapat mengajukan IUPK, meliputi BUMN, BUMD, dan BUS. Sedangkan pemohon IUP terdiri dari badan usaha, koperasi dan perseorangan. Jadi, pemohon IUP dapat perseorangan.

3) Objek mineral dan logam dan batubara, sedangkan IUP meliputi mineral logam, bukan logam dan batubara.

4) Cara pemberian WIUPK, meliputi prioritas dan lelang.

5) WIUPK nya cukup luas. Untuk IUPK Eksplorasi Mineral dan Logam, seluas 100.000 (seratus ribu) hektare, IUPK Produksi seluas 25.000 hektare. IUPK Eksplorasi Batubara seluas 50.000 (lima puluh ribu) hektare dan IUPK Produksi Batubara seluas 15.000 hektare.

6) Jangka waktunya cukup panjang, yaitu 48 tahun $^{8}$.

Hal di atas, merupakan krakteristik dari IUPK yang tercantum dalam Undang-Undang No. 4

\footnotetext{
${ }^{8}$ Salim, HS, Hukum Pertambangan Mineral dan Batubara, Op.cit, hal 158-159
} 
Tahun 2009. IUPK merupakan pengganti sistem pengelolaan pertambangan yang menggunakan sistem kontrak, baik dalam bentuk kontrak karya maupun perjanjian karya pengusahaan pertambangan batubara (PKP2B), sedangkan IUP merupakan pengganti dari kuasa pertambangan (KP). Dengan demikian kerjasama usaha pertambangan model Kontrak Karya kini telah berakhir, seiring dengan diterbitkannya Undang-Undang Penanaman Modal No. 25 Tahun 2007 dan Undang-Undang Minerba No. 4 Tahun 2009 yang telah menentukan bahwa sebagai pengganti kontrak karya investasi pertambangan modal asing adalah menggunakan IUPK. Penjelasan Pasal 169 Huruf b menyebutkan bahwa "Semua pasal yang terkandung dalam kontrak karya dan perjanjian karya pengusahaan pertambangan batubara harus disesuaikan dengan UndangUndang". Akibat hukum bagi pemegang KK dan PKP2B yang tidak mengindahkannya ketentuan Pasal 169 Undang-Undang Minerba, tidak menyampaikan rencana kegiatan pada seluruh wilayah kontrak sampai dengan berakhirnya kontrak paling lambat 1 (satu) tahun sejak berlakunya kontrak ini, maka berdasarkan Pasal 171 Undang-Undang Minerba, luas wilayah pertambangannya akan disesuaikan dengan Undang-Undang ini. Dalam ketentuan Pasal 83 huruf a Undang-Undang Minerba menyebutkan bahwa "luas 1 (satu) WIUPK untuk tahap kegiatan eksplorasi pertambangan mineral logam diberikan dengan luas paling banyak 100.000 (seratus ribu) hektare.

\section{B. Implikasi Izin Usaha Pertambangan Bagi Perusahaan Pertambangan}

Pemberlakuan Kebijakan Undang-Undang Nomor 4 tahun 2009 Tentang Pertambangan Mineral Batubara membuat shock bagi kalangan pengusaha pertambang domestik dan investor asing. Shock tersebut disebabkan atas ketidaksiapan mereka dalam menyambut kebijakan baru pertambangan mineral batubara, yang mana pada kebijakan baru tersebut tidak diperbolehkan mengekspor bahan tambang mentah terhitung sampai 12 Januari $2014^{9}$.

\footnotetext{
${ }^{9}$ Siti Nuraisyah Dewi dan Arie Dwi Budiawati, "Kala UU Minerba Jadi Polemik Pertambangan", Artikel Online, Diakses dari https://www.bisnis.news.viva.co.id/news/read/469951-
}

Undang-Undang Nomor 4 Tahun 2009 tersebut disetujui oleh DPR pada tanggal 16 desember 2008, dan disahkan menjadi UndangUndang Nomor 4 Tahun 2009 setelah mendapat persetujuan Presiden Susilo Bambang Yudhoyono pada tanggal 12 Januari 2009.

Pasal 169 UU No. 4 Tahun 2009 tentang Pertambangan Mineral dan Batubara memuat pasal pengalihan sebagai berikut:

a. Kontrak Karya dan Perjanjian karya pengusahaan pertambangan batubara yang telah ada sebelum berlakunya UU ini tetap diberlakukan sampai jangka waktu berakhirnya kontrak/perjanjian;

b. Ketentuan yang tercantum dalam pasal kontrak karya dan perjanjian karya pengusahaan pertambangan batubara sebagaimana dimaksud pada huruf a disesuaikan selambat-lambatnya 1 (satu) tahun sejak Undang-Undang ini diundangkan kecuali mengenai penerimaan negara.

Ketentuan dalam ayat (a) memuat bahwa KK dan PKP2B yang tetap dihormati sampai dengan habis masa berlakunya. Hal ini penting karena pemerintah sebagai institusi publik tidak melakukan penyalahgunaan kekuasaan (abuse of power) atas kedudukannya sebagai subjek hukum perdata. Kalau KK dan PKP2B dipaksa tunduk pada rezim perizinan UU Minerba, maka pemerintah bisa dituduh melanggar prinsip Pacta Sunt Servanda (Perjanjian itu mengikat para pihak yang menyepakatinya) ${ }^{10}$.

Namun ketentuan dalam ayat (a) dirasa kontradiktif dengan ketentuan yang dimuat dalam ayat (b) karena disini ada paksaan bahwa KK dan PKP2B yang sudah berlaku harus disesuaikan dengan UU No.4 Tahun 2009 tentang Pertambangan Mineral dan Batubara dengan jangka waktu selambat-lambatnya 1 tahun sejak Undang-Undang ini diundangkan ${ }^{11}$. Sebenarnya ketentuan dalam pasal 169 huruf (b) menurut Prof. Hikmahanto Juwana bukan merupakan hal yang aneh mengingat berdasarkan Pasal 1338 KUH Perdata ditentukan bahwa perjanjian tidak boleh bertentangan dengan hukum kesusilaan, dan

kala-uu-minerba-jadi-polemik-pertambangan pada tanggal 19 November 2019 pukul 10.00 WITA

${ }^{10}$ Kitab Undang-Undang Hukum Perdata, Ps 1338

${ }^{11}$ Undang-Undang No 4 Tahun 2009, Ps 169 
kepatutan. Bila bertentangan akan berakibat batalnya perjanjian tersebut. Oleh karena itu, memang harus dilakukan negosiasi ulang antara Pemerintah Indonesia dengan investor asing terhadap ketentuan KK yang bertentangan dengan UU No.4 Tahun 2009 tentang Pertambangan Mineral dan Batubara ${ }^{12}$.

Meskipun KK yang masih ada tetap dihormati sampai habis jangka waktunya bukan berarti keberadaan UU No. 4 Tahun 2009 ini tidak memberikan pengaruh terhadap KK yang masih ada. Keberadaan ketentuan peralihan pada Pasal 169 b UU No.4 Tahun 2009 merupakan dasar hukum yang mengamanatkan bahwa KK yang telah ada harus disesuaikan selambat-lambatnya 1 (satu) tahun sejak UU No.4 Tahun 2009 diundangkan.

Terkait dengan aturan peralihan yang terdapat dalam UU No.4 Tahun 2009 tentang Pertambangan Mineral dan Batubara, dapat dilihat bahwa pemerintah Indonesia bertekad untuk mengadakan reformasi terhadap sektor pertambangan secara bertahap. Setiap reformasi atau perubahan akan menuju kepada sesuatu yang baru atau paling tidak sekedar berbeda dengan yang lama (diubah) maupun kepada yang baru (hasil perubahan). Untuk mengurangi masalah dari sebuah perubahan, maka dalam setiap perubahan terlebih dahulu dibuatkan pedoman atau tata cara pelaksanaan dan akibat perubahan yang biasa disebut peralihan atau masa transisi ${ }^{13}$.

Aturan peralihan pada hakekatnya bertujuan untuk menjaga kekosongan hukum (rechtvacuum) dan menjamin kepastian hukum (legal certainity) akibat dari adanya perubahan baik kelembagaan maupun materi (substance) peraturan perundang-undangan. Melihat tujuan utama dari aturan peralihan dapat dipahami bahwa aturan peralihan sesungguhnya untuk memberikan kemudahan pada masa transisi dan menyederhanakan masalah yang ditimbulkan oleh masa transisi atau perubahan. Oleh karena itu, setiap aturan peralihan dalam sebuah peraturan perundangundangan seharusnya memberikan ruang kemudahan, dan tidak menciptakan masalah/kesulitan baru.

$12 \quad$ https://www.inspirasibangsa.com/renegosiasiperusahaan-pertambangan/ diakses pada tanggal 20 November 2019, pukul 00.00 WITA

${ }^{13}$ Adrian Sutedi, Hukum Pertambangan, Op.cit Hal 22-23
Berdasarkan amanat pasal 169 b UU No.4 Tahun 2009 dapat dilihat ada 6 (enam) isu strategis untuk disepakati/direnegosiasi yaitu ${ }^{14}$ :

a. Luas wilayah kerja

b. Perpanjangan kontrak

c. Penerimaan negara

d. Kewajiban divestasi

e. Kewajiban pengolahan dan pemurnian

f. Kewajiban penggunaan barang dan jasa dalam negeri

Terkait luas wilayah, UU No. 4 Tahun 2009 tentang Pertambangan Mineral dan Batubara mengamanatkan luas wilayah eksplorasi dibatasi hingga maksimal 100.000 hektare, serta maksimal 25.000 hektar untuk wilayah operasi. Sedangkan mengenai jangka waktu kontrak, ditetapkan paling lama 20 tahun dan dapat diperpanjang masing-masing 10 tahun $^{15}$. Pemegang izin operasi produksi yang telah memperoleh perpanjangan sebanyak 2 kali harus mengembalikan wilayah operasinya kepada pemerintah Indonesia.

Sedangkan terkait dengan kewajiban divestasi yang dilakukan oleh perusahaan pertambangan adalah Perusahaan Pertambangan wajib berproduksi wajib melakukan divestasi sahamnya secara bertahap, sehingga pada tahun kesepuluh sahamnya paling sedikit $51 \%$ (lima puluh satu persen) dimiliki peserta Indonesia ${ }^{16}$. Divestasi sendiri memliki pengertian Linn \& Rozeft. la mendefinisikan sell-off sebagai penjualan sub bagian, divisi, atau lini bisnis oleh suatu perusahaan ke perusahaan lain. Selloff merupakan bentuk sederhana dari divestiture, proses yang merupakan kontraksi bagi perusahaan yang menjual namun menjadi alat untuk ekspansi bagi perusahaan yang membelinya ${ }^{17}$.

Untuk kewajiban pengolahan, pemegang izin pertambangan batubara wajib meningkatkan nilai tambah sumber daya mineral dalam pelaksanaan penambangan, pengolahan, dan pemurnian serta pemanfaatan mineral. Nilai tambah dimaksudkan untuk meningkatkan produk akhir dari usaha pertambangan atau pemanfaatan terhadap

\footnotetext{
${ }^{14}$ Undang-Undang Nomor 4 Tahun 2009, Op.cit

${ }^{15}$ Undang-Undang Nomor 4 Tahun 2009 Ps. 55-62

${ }^{16}$ PP No. 1 Tahun 2017, Ps 97

${ }^{17}$ Hendrik Budi Untung, Hukum Investasi,(Jakarta: Sinar Grafika, 2010), hal.28
} 
mineral ikutan oleh karena itu perusahaan wajib melakukan pengolahan dan pemurnian dengan membangun pabrik pengolahan $(\text { smelter })^{18}$.

\section{PENUTUP}

\section{A. Kesimpulan}

1. Dengan adanya Undang-Undang Nomor 4 Tahun 2009 tentang Mineral dan Batubara telah merubah sistem investasi pertambangan batubara dari sistem kontrak menjadi sistem perizinan. Jika dalam sistem kontrak kedudukan antara pemerintah dengan investor adalah sama/sejajar dimana pemerintah berlaku sebagai pelaku usaha, berbeda halnya dalam sistem perizinan yang membuat kedudukan pemerintah menjadi lebih tinggi dari investor, dimana pemerintah berkedudukan sebagai regulator. Perubahan kedudukan ini dilihat dari aspek ketatanegaraan adalah sebuah langkah yang baik karena pemerintah sebagai badan hukum publik tidak menurunkan derajatnya menjadi badan hukum privat sebagaimana yang telah dilakukan pemerintah dalam sistem kontrak.

2. Keberadaan pasal 169 (b) UU No. 4 Tahun 2009 telah membawa implikasi serius tentang pertambangan mineral dan batubara di sektor pertambangan. Bila pasal 169 (a) Undang-Undang Nomor 4 Tahun 2009 mengakui keberadaan KK/PKP2B, pasal 169 (b) justru mengabaikannya. Perusahaan Pertambangan pun juga turut menyesuaikan dengan aturan dari pemerintah yang ada, sehingga ketegasan dari aturan yang dikeluarkan tersebut bersifat tegas dan mengikat perusahaan pertambangan yang ada.

\section{B. Saran}

1. Keputusan pemerintah untuk lebih mempertegas aturan yang ada serta menyelaraskannya dengan keadaan masyarakat masa kini sudah sangat baik. Namun, untuk membuat suatu peraturan diperlukan kejelasan dan tidak bertentangan antara aturan satu dengan

${ }^{18}$ Undang-Undang Nomor 4 Tahun 2009, Ps 103 yang lain. Sehingga investor asing pun menjadi tidak ragu untuk menanamkan modalnya yang tentu bisa membantu perekonomian negara Indonesia itu sendiri.

2. Pemerintah juga perlu untuk membentuk suatu komisi pengawasan sumber daya alam tersendiri untuk lebih fokus lagi dalam mengawasi aturan dan penerapan peraturan yang sudah dibuat.

\section{DAFTAR PUSTAKA}

BUKU:

Simon F. Sambiring, Jalan Baru Untuk Tambang: Mengalirkan Berkah bagi Anak Bangsa

Adrian Sutedi, Hukum Pertambangan, Jakarta: PT. Sinar Grafika

George W. Pring, Mining, Environment and Development: International Law and Mineral Resources, (Denver: UNCTAD, 1999)

Salim HS, Hukum Pertambangan Di Indonesia.

Soerjono Soekanto. Sri Mamudji. Penelitian Hukum Normatif Suatu Tinjauan Singkat. Jakarta. PT. Raja Grafindo Persada. 2013.

Departemen Pendidikan Nasional, Kamus Besar Ikthasar Indonesia Edisi Ketiga, Jakarta : Balai Pustaka. 2005.

Sudarsono, Kamus Hukum, Jakarta: Rincka Cipta, 2007.

Mariam Darus, KUH Perdata Buku III Hukum Perikatan dengan Penjelasan, PT. Alumi Bandung. 2005.

Salim MS, Hukum Kontrak, Teori \& Tekniik Penyusunan Kontrak, Jakarta : Sinar Grafika, 2008.

M. Husni, Tinjauan Umum Mengenai Hontrak. 2009.

Philipus M. Hadjon, Pengantar Hukum Perizinan, Surabaya: Yuridika, 1993

Y. Sri Pudyatmoko,Perizinan Problem dan Upaya Pembenahan, Jakarta: Grasindo, 2009.

Ridwan HR, Hukum Administrasi Negara, Jakarta: PT Raja Grafindo Persada, 2006.

Hendrik Budi Untung, Hukum Investasi, Jakarta: Sinar Grafika, 2010. 
Badan Pengkajian dan Pengembangan Kebijakan Perdagangan, Pusat Kebijakan Perdagangan Luar Negeri.Analisis Dampak Kebijakan Pelarangan Ekspor Raw Material Tambang Dan Mineral.Jakarta.2013.

Nanik Trihastuti, Hukum Kontrak Karya, Jakarta: Setara Press, 2013.

Jusri Djamal, Aspek-aspek Hukum Masalah Penanaman Modal, Jakarta: BKPM, 1982.

\section{PERATURAN PERUNDANG-UNDANGAN}

Lampiran Peraturan Pemerintah Nomor 38 Tahun 2007 tentang Pembagian Urusan Pemerintah, Pemerintah Daerah Provinsi, Dan Pemerintah Daerah Kabupaten/Kota bagian Pembagian Urusan Pemerintah Bidang Energi dan Sumber Daya Mineral

Kitab Undang-Undang Hukum Perdata,

Peraturan Pemerintah Nomor 1 Tahun 2017 tentang Perubahan Keempat Atas Peraturan Pemerintah Nomor 23 Tahun $2010 \quad$ Tentang Pelaksanaan Kegiatan Usaha Pertambangan Mineral dan Batubara

Konsideran Undang-Undang Nomor 4 Tahun 2009 tentang Pertambangan Mineral dan BatuBara

WEBSITE:

http://www.kemendag.g.id/files/pdf/2015/ 02/02/analisis-dampakkebijakan1422852872.pdf diakses pada 2 November 2019

https://id.wikipedia.org/wiki/Pertambanga n, diakses pada 1 Oktober 2019 pukul 02.00 WITA

Ensiklopedia Indonesia, tt:1349, diakses pada 30 September 2019 pukul 22.03 WITA.

Black law Dictionary, 1982:847, diakses pada 30 September 2019 pukul 22.45 WITA.
Article 11 Japanese Mining Law, No 289, 1950 Latest Amandement In 1962, diakses pada 30 September 2019 pukul 22.45 WITA.

https://www.academia.edu/4757061/asasasas_hukum_pertambangan_mine ral_dan_batubara diakses pada 1 oktober 2019 pukul 05.33 WITA

https://www.esdm.go.id/id/mediacenter/arsip-berita/kesepakatanfinal-perundingan-antarapemerintah-dan--pt-freeportindonesia, Kesepakatan Final Perundingan Antara Pemeritah dan PT Freeport Indonesia, diakses pada tanggal 19 November 2019 Pukul 2.44 WITA.

https://finance.detik.com/energi/3466745/ penjelasan-lengkap-esdm-soalpemberian-iupk-ke-freeport, Penjelasan lengkap ESDM Soal Pemberian IUPK ke Freeport, diakses pada tanggal 19 November 2019 pukul 3.35 WITA.

Siti Nuraisyah Dewi dan Arie Dwi Budiawati, "Kala UU Minerba Jadi Polemik Pertambangan", Artikel Online, Diakses dari https://www.bisnis.news.viva.co.i d/news/read/469951-kala-uuminerba-jadi-polemikpertambangan pada tanggal 19 November 2019 pukul 10.00 WITA https://www.inspirasibangsa.com/renegosi asi-perusahaan-pertambangan/, diakses pada tanggal 20 November 2019, pukul 00.00 WITA 